\title{
PEMBERDAYAAN MASYARAKAT DESA SIMPUR MENJADI MASYARAKAT YANG MANDIRI DENGAN PENGEMBANGAN POTENSI PERTANIAN DAN PETERNAKAN
}

\author{
Rahmawati $^{1 *}$, Husna Gemasih ${ }^{2}$, Zulida Susanti $^{3}$ \\ ${ }^{1}$ Program Studi Peternakan, Fakultas Pertanian, Universitas Gajah Putih Takengon, Aceh Tengah, Indonesia \\ ${ }^{2}$ Jurusan Teknik Informatika, Fakultas Teknik, Universitas Gajah Putih Takengon, Aceh Tengah, Indonesia \\ ${ }^{3}$ Jurusan Budidaya Perairan, Fakultas Pertanian, Universitas Gajah Putih Takengon, Aceh Tengah, Indonesia \\ *Penulis Korespodensi: rahmawatiugp@gmail.com
}

\begin{abstract}
Abstrak
Tujuan yang ingin dicapai pada program Kuliah Kerja Nyata-Pembelajaran Pemberdayaan Masyarakat (KKN-PPM) Universitas Gajah Putih Takengon Tahun 2018 di Desa Simpur adalah pemberdayaan masyarakat di bidang pertanian dan peternakan sesuai dengan potensi sumber daya alam dan sumber daya manusia yang dimiliki Desa Simpur. Meningkatkan perekonomian masyarakat dengan memaksimalkan potensi pertanian dan peternakan yang terdapat di Desa Simpur dengan beberapa program yakni pembuatan kompos dari kotoran sapi, penyusunan ransum ternak sapi dan pembuatan ransum fermentasi, pembuatan perangkap hama, penanaman cabe kopay tumpang sari dengan bawang merah. Menciptakan kemandiriaan energi dengan pembuatan instalasi biogas karena Desa Simpur belum semua lokasi dialiri listrik PLN. Adapun metode yang digunakan untuk mencapai tujuan tersebut adalah 1)Penyuluhan, 2)Demontrasi, 3)Membuat kebun percontohan, 4)Pratek langsung, 5)Mengadakan monitoring, evaluasi perkembangan setiap program yang dijalankan secara berkala.
\end{abstract}

Kata kunci : Pemberdayaan masyarakat, cabe kopay, perangkap hama, kompos, biogas.

\begin{abstract}
The aim to be achieved in the Takengon Gajah Putih University Community Service Program activities in 2018 in Desa Simpur is community empowerment in agriculture and livestock in accordance with the potential of natural resources and human resources owned by the village of Simpur. Improving the economy of the community by maximizing the potential of agriculture and livestock in Simpur Village with several programs namely composting from cow dung, compiling cattle rations and making fermentation rations, natural pest control, planting Kopay Chilli intercropping with shallots. Creating energy independence by making biogas installations because the village of Simpur has not been electrified by PLN. Improve the performance of village officials by computer training and making village websites. The methods used to achieve these objectives are 1) Counseling 2) Demonstration and Experiments 3) Making Kopay Chilli Pilot Gardens 4) Direct Pratek 5) Conducting monitoring, evaluating the progress of each program that is run regularly.
\end{abstract}

Keywords: community empowerment, kopay chili, pest traps, compost, biogas.

\section{PENDAHULUAN}

Desa Simpur terletak di Kecamatan Mesidah, Kabupaten Bener Meriah, Propinsi Aceh. Karena kondisinya Desa Simpur bisa dikategorikan sebagai desa tertinggal dan terisolir. Jarak Desa Simpur dari Ibu Kota Kecamatan Mesidah lebih kurang $20 \mathrm{~km}$ dengan kondisi jalan tanah, berlumpur apabila hujan. Dengan topografi perbukitan dengan kondisi jalan becek mengakibat jarak tempuh dari Kecamatan ke Desa Simpur mencapai 1 jam. Sampai saat ini transportasi umum belum tersedia. Transportasi yang digunakan warga saat ini dengan menyewa sepeda motor dengan biaya 150.000 rupiah setiap keberangkatan. Keadaan ini merupakan faktor utama penyebab ketertinggalan Desa Simpur. Disamping itu antar dusun di Desa Simpur kondisi jalan lebih buruk apalagi setelah hujan turun, sehingga transportasi antar dusun tidak lancar.

Disamping itu penyebab lain Desa Simpur mengalami ketertinggalan adalah Desa Simpur baru dialiri listrik pada saat program KKN-PPM berlansung yakni pada bulan Februari 2018.Tapi belum semua lokasi dialiri listrik karena jarak antar rumah warga ada berjauhan. Pada saat ini bagi warga yang mampu mereka memakai gengset atau listrik tenaga surya. Begitu juga dengan sinyal telpon seluler belum tersedia di Desa Simpur ini sangat menyulitkan masyarakat untuk mengupdate informasi. Keterbatasan informasi dan pengetahuan membuat desa simpur menjadi desa yang 
tertinggal dibandingkan dengan desa-desa lainnya. Potensi ekonomi di desa ini pada bidang pertanian meliputi peternakan, perkebunan dan tanaman palawija, dimana di bidang peternakan beberapa masyarakat memelihara hewan ternak seperti sapi dan kerbau sementara di bidang perkebunan masyarakat kebanyakan menanam tanaman kopi dan beberapa tanaman palawija seperti tanaman cabe dan tanaman tomat. Sehingga rata-rata mata pencarian warga simpur adalah sebagai petani pekebun dengan beberapa petani memiliki hewan ternak. Disamping desa simpur juga akan diberi batuan tambahan ternak sapi, jadi perlu persiapan untuk menerima bantuan sapi tersebut agar berhasil.

Profil masyarakat simpur desa simpur di huni oleh 65 Kepala Keluarga dengan suku bangsa yang beragam. Kesadaran pendidikan dan kesehatan masyarakat yang masih rendah. Sarana transportasi, komunikasi dan penerangan belum ada. Rata-rata mata pencarian penduduk adalah sebagai petani. Masyarakat rata-rata merupakan warga kurang mampu dengan tingkat pendidikan yang rendah.

Dari kondisi tersebut maka perlu diadakan suatu kerja sama dengan pemerintah Desa Simpur dalam memberikan pengetahuan kepada masyarakat, alih teknologi berupa pelatihan dan penyuluhan pada program-program yang diusulkan melalui KKN-PPM Universitas Gajah Putih. Berdasarkan survey lapangan, wawancara dengan warga desa dan hasil diskusi dengan Reje Desa Simpur dan Camat Kecamatan Mesidah tentang pokok-pokok permasalahan yang urgen untuk diatasi, maka program KKN-PPM Universitas Gajah Putih Tahun 2018 mengangkat program:

\section{a) Listrik Biogas}

Di era mordenisasi ini masih ada sebagain kecil desa di wilayah NKRI yang belum dialiri oleh listrik, desa simpur merupakan salah satunya. Berdasarkan hasil survey tim penggagas KKN-PPM, Desa Simpur berada dekat sentra lokasi peternakan di Kab. Bener Meriah. Oleh karena itu maka program KKK-PPM ini, kita akan mengembangkan sumber energi listrik tenaga biogas dari kotoran sapi, dimana sumber energinya banyak tersedia dilokasi. Dan pembuatan instalasi biogas juga sederhana, dengan biaya murah dan sudah banyak digunakan di pedesaan.

\section{b) Pakan Fermentasi dari Limbah Pertanian dan Menyusun Ransum Ternak Sapi}

Dengan adanya program ini mendukung program pemerintah yang sudah berjalan di Desa Simpur, sebagai sentra peternakan Sapi. Dalam program ini penduduk diberi penyuluhan tentang budidaya ternak sapi secara modern, sehingga dihasilkan produksi ternak yang maksimal. Bagaimana menyusun ransum ternak sapi dan membuat pakan fermentasi dari limbah pertanian (Munier, 2010). c) Membuat Pupuk Kompos dari Titonia dan Kotoran Ternak

Penggunaan pupuk alami lebih menguntungkan dibandingkan pupuk buatan. Harga murah, tidak menimbulkan pencemaran tanah, kesuburan biologi tanah dapat dipertahankan dan komuditas pertanian yang dihasilkan lebih sehat (Mala, 2013). Apalagi dengan kondisi jalan yang tidak bersahabat di Desa Simpur pupuk tidak tersedia. Sehingga banyak petani tidak menggunakan pupuk di Desa Simpur. Jadi dalam program ini diadakan pelatihan pembuatan pupuk kompos dari bahan Titonia dan kotoran ternak.

\section{d) Sistem Penanaman Cabe Kopay}

Desa Simpur masyarakatnya rata-rata sebagai petani, salah satu komuditi yang mereka usahakan adalah cabe. Setelah dilakukan survey di lapangan, varietas cabe yang diusakan adalah jenis cabe kampung bukan cabe unggul. Jadi dalam program KKN PPM ini kita akan membuat Kebun Cabe Unggul, dengan menanam cabe kopay. Keunggulan cabe ini produksi tinggi, dengan panjang buah cabe rata-rata $25 \mathrm{~cm}$, awet disimpan/penjalanan jauh, tahan terhadap hama, dapat ditumpangsarikan dengan tanaman bawang, tomat dan jagung.

\section{e) Pembuatan Perangkap Hama}

Budidaya Tanaman palawija tidak bisa lepas dari pestisida, terutama tanaman cabe sangat tergantung pada penggunaan pestisida secara rutin, ini merupakan pemborosan dana dan berbahaya terhadap kesehatan manusia dan lingkungan hidup. Untuk itu perlu kita kembangkan pengendalian hama dengan cara alami (Shahabuddin, 2012).

Itulah beberapa program yang dilakukan pada kegiatan KKN-PPM Universitas Gajah Putih tahun 2018 di Desa simpur dengan harapan dapat menyelesaikan permasalahan yang ada di Desa Simpur yakni : 1) mengatasi keterbatasan energi listrik 2)mengatasi kelangkaan pupuk 3) mengembangkan komunitas cabe unggul untuk meningkatkan produksi 4)Meningkatkan keterampilan peternak dengan pelatihan pembuatan pakan ternak fermentasi 5) Pemberantasan hama pertanian secara alami dengan membuat perangkap hama. Jadi tujuan kegiatan KKNPPM ini adalah pemberdayaan masyarakat Desa Simpur dengan pengembangan potensi pertanian dan peternakan menjadi sumber daya manusia yang mandiri.

\section{METODE PELAKSANAAN}

Program KKN-PPM di desa Simpur Kec. Mesidah Kab. Bener Meriah yang telah dilaksanakan sejak 22 Februari 2018 sampai dengan 21 Maret 2018.

Adapun metode yang dipakai untuk mencapai tujuan pada kegiatan ini adalah :

\section{a) Demontrasi dan Eksperimen}

Menjelaskan dan mempraktekkan langsung bagaimana cara membuat instalasi biogas dan cara kerjanya. Mempraktekan langsung di depan warga 
bagaimana membuat pakan fermentasi, menyusun ransum pakan sapi dengan bahan-bahan lokal. Begitu juga dengan program pembuatan perangkap hama.

b) Membuat Kebun Percontohan

Cabe Kopay dengan tumpang sari bawang merah dibuat kebun percontohannya. Dimana setiap tahap pekerjaan warga diajak ikut serta.

c) Pendekatan dengan komunikasi langsung face to face

Setiap ada kesempatan bertemu warga atau kepala dusun, melakukan pendekatan persuasif, meningkatkan pemahaman dan melihat feed back dari warga.

\section{d) Mengadakan Monitoring}

Melakukakan pengawasan dan evaluasi perkembangan setiap program yang dijalankan secara berkala.

\section{HASIL DAN PEMBAHASAN}

\subsection{Biogas}

Jadi biogas merupakan salah satu energi alternatif yang dapat dikembangkan di Kampung Simpur. Sebelum pemasangan instalasi biogas dilakukan terlebih dahulu penyuluhan bagaiman cara kerja dan cara pemasangan instalasi biogas dengan mengumpulkan masyarakat Simpur, dihadiri juga oleh aparat kampung, Pak Dusun, Pak Reje dan Mahasiswa peserta KKN PPM di Kampung Simpur. Begitu juga dengan Mahasiswa sebanyak 60 orang di kumpulkan di Balai Desa di berikan materi lengkap dengan Video : 1)Prinsip kerja Instalasi Biogas, 2)Jenis Instalasi Biogas, 3)Bahan-bahan organik penghasil biogas, 4)Cara pemasangan instalasi biogas 4)Cara pemasangan lampu petromak dan kompor biogas. Di Kampung simpur kita membuat jenis instalasi biogas terapung, yang terdiri dari tangki politank sebagai digester, ada bak inlet permanen dari batu bata yang di cor semen. Bak inlet tempat memasukan kotoran sapi cair yang sudah dicampur dengan air 1 : 1 . Kotoran sapi yang dipakai adalah kotoran sapi yang masih baru. Ada bak outlet tempat keluarnya hasil sisa fermentasi biogas yang bisa digunakan sebagai pupuk.

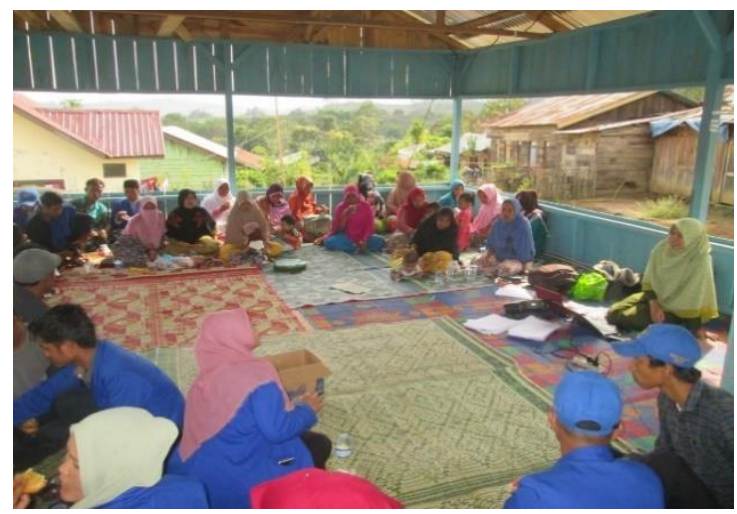

Gambar 1. Penyuluhan Biogas

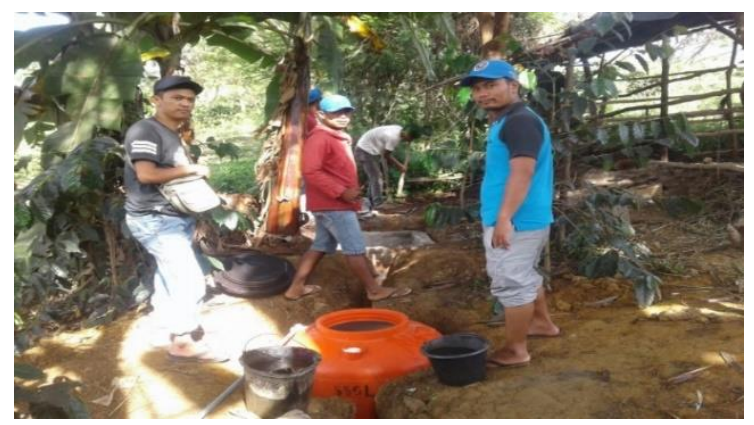

Gambar 2. Pembuatan Instalasi biogas

\subsection{Menyusun Ransum Ternak Sapi dan Membuat Pakan Fermentasi}

Kampung Simpur bertetangga dengan Pusat Pengembangan Peternakan dan sangat potensial di masyarakatnya untuk beternak terutama ternak besar. Di Kapung simpur saja terdapat sekitar 100 ternak kerbau, 60 ekor sapi. Sehingga masyarakat simpur perlu dibekali pengetahuan tentang menyusun ransum ternak Ruminansia.

Pada kesempatan ini kami merekomendarikan untuk menyusun ransum dari leguminosa yang tumbuh subur di kampung simpur. Berdasarkan hasil obsevasi kami dilapangan di kampung Simpur banyak hidup leguminosa dengan kandungan protein yang tinggi seperti Kaliandra, Gamal, Petai China dimana legume tersebut belum diberikan kepada ternak mereka. Jadi disini kami mengumpulkan peternak mengenalkan leguminosa pakan ternak ini dan memberikan kombinasi penyusunan ransum dari leguminosa yang terdapat dilokasi sebagai pakan ternak Kerbau dan Sapi. Disamping itu juga kami mengenalkan cara pembuatan pakan fermentasi dengan probiotik dengan bahan dasar kulit kopi yang banyak terdapat di Kampung Simpur.

\subsection{Membuat Pupuk Kompos dari Kotoran Ternak dan Titonia}

Kampung Simpur merupakan daerah tempat berkebun warga Kab. Bener Meriah dan warga Takengon. Hasil Utama warga simpur disamping tanaman kopi sebagai tanaman utama juga menghasilkan tanaman muda seperti cabe, bawang merah, tomat. Mayoritas penduduknya bermata pencaharian sebagai petanipekebun. Maka dari itu pupuk merupakan kebutuhan vital oleh warga simpur, apalagi lokasi Simpur yang jauh dari pusat kota 2,5 jam dari Pondok, Ibu Kota Kabupaten Bener Meriah. Dengan kondisi jalan yang tidak memungkinkan sangat sulit membawa pupuk ke Simpur.

Maka dari itu kami kami berpikir untuk membuat kompos dari bahan2 yang tersedia dilokasi tanpa dibawa dari jauh. Tercetuslah ide untuk membuat kompos dengan bahan-bahan :1)Kotoran sapi segar1 ton, 2)Titonia $200 \mathrm{~kg}$, 3)TSP (rock pospat) $10 \mathrm{~kg}$, 4)Dolomit $20 \mathrm{~kg}$ 5)Serbuk gergaji 1 karung. 6) Abu sekam $1 \mathrm{krg}$ 7) MOL 5 liter. 


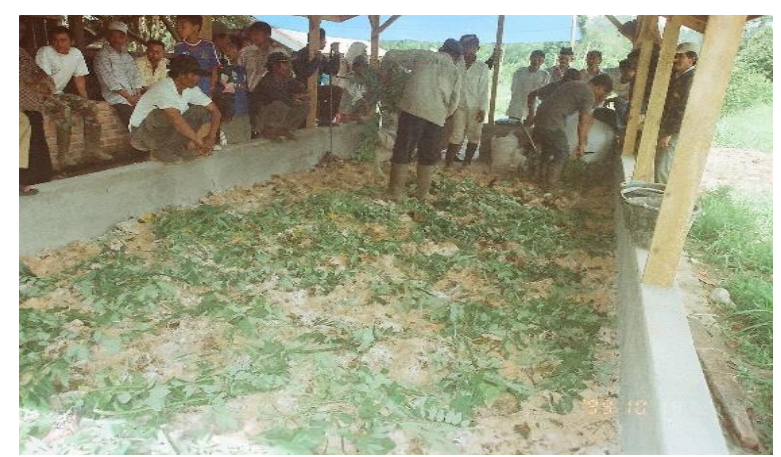

Gambar 3. Kompos dari Titonia dan Kotoran Sapi

\subsection{Sistem Penanaman Tumpang Sari Cabe Kopay dengan Bawang Merah}

Program ini dilakukan pada kegiatan hari pertama kegiatan KKN PPM karena penanaman cabe kopay membutuhkan waktu yang lama untuk sampai panen. Apabila perawatannya baik cabe kopay panen perdana pada umur 3-4 bulan. Kegiatan ini diawali dengan memberikan penyuluhan kepada kepada masyarakat simpur terutama yang mempunyai usaha sebagai petani cabe. Penyuluhan dilakukan di balai desa yang dihadiri lebih kurang 60 orang yang terdiri dari masyarakat desa, aparat kampung, mahasiswa peserta KKN dan para Dosen Pembimbing Lapangan (DPL).
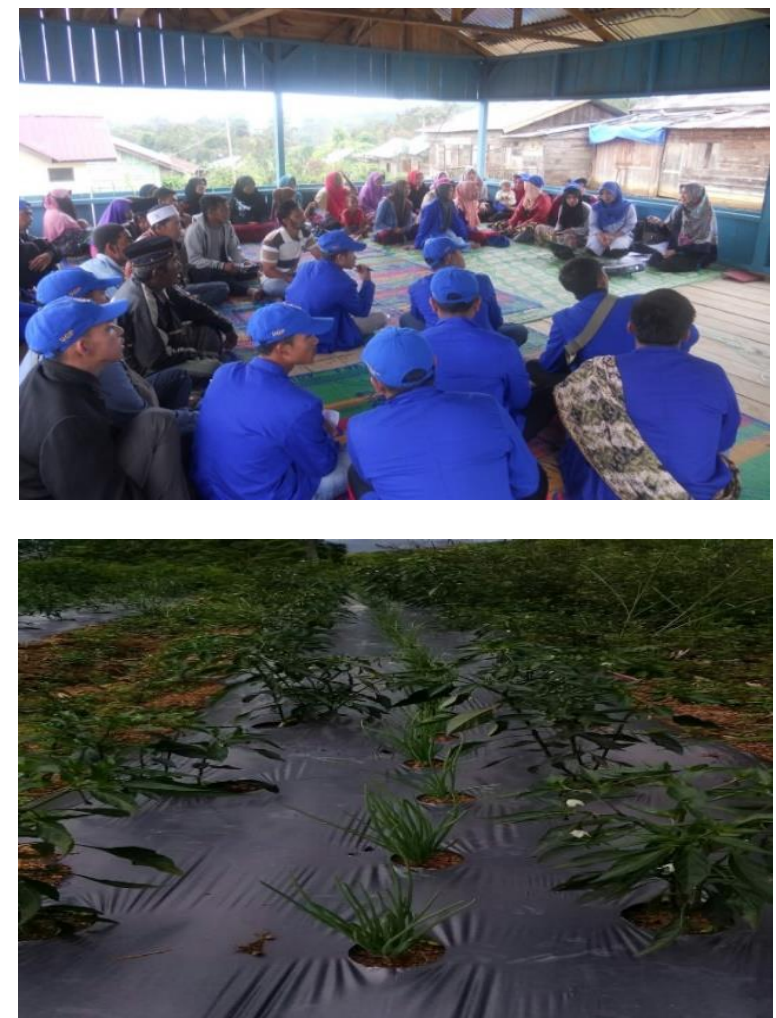

Gambar 4. Penyuluhan dan Penanaman Cabe Kopay Tumpangsari Bawang Merah

Penyuluhan diawali dengan pengenalan cabe kopay sebagai cabe keriting uanggul kepada peserta penyuluhan. Cabe kopay adalah cabe unggul, cabe keriting raksasa yang berasal dari Kota Payakumbuh, Sumatera Barat. Cabe kopay memiliki banyak keunggulan diantaranya tahan terhadap penyakit, memiliki buah yang lebih besar dan panjang dari cabe kampung yaitu mencapai $25-27 \mathrm{~cm}$. Buah yang dihasilkan tidak mudah busuk, karena mempunyai kadar air yang rendah, sehingga tahan disimpan lebih lama dibandingkan cabe kampung. Produksi satu batang pohon cabe menghasilkan jumlah yang lebih banyak dibandingkan cabe kampung. Harga jual cabe kopay tentu lebih tinggi dibandingkan cabe kampung, karena cabe kopay merupakan cabe kriting kualitas super.

Masyarakat diberikan materi bagaimana cara membudidayakan cabe kopay, dimulai dari persiapan lahan yang meliputi land clearing, penggemburan tanah, pembuatan bedengan, pemberian pupuk dasar (pupuk kandang dan pupuk kimia), pencincangan tanah dan pengadukan pupuk dasar, pemasangan mulsa. Dilanjutkan dengan cara pembibitan, penanaman cabe ke lahan, perawatan, pemupukan cair, pembuangan tunas sela, pemasangan ajir, pemberian pestisida nabati.

Para peserta cabe kopay diberi tau tips agar :1)Tips pengolahan lahan agar cabe kopay bisa tumbuh tinggi mencapai 2 meter dan bisa tumbuh selama 2 tahun. Umur cabe keriting yang di tanam oleh warga simpur rata2 berumur kurang dari 1 tahun sudah mesti tanam ulang. Cara pengolahan tanahnya dimana pupuk dasar benar-benar sudah matang dengan cara menutup bedengan dengan mulsa selama 2 bulan, baru dilobang untuk tempat tanam.

2)Tips dosis pupuk kandang dan pupuk kimia, agar produksi cabe maksimal, yaitu dengan perbandingan pemberian pupuk kandang yag terdiri dari kotoran sapi kotoran ayam plus pupuk kimia. Dimana pupuk kandang 2-3 $\mathrm{kg}$ per lobang. Disamping itu ditambahakan pupuk ZA, TSP, NPK. Setelah cabe dipindah ke bedengan selama 15 hari, diberikan pupuk NPK Mutiara yang dicairkan dengan air dengan dosis $1 \mathrm{~kg}$ pupuk dengan 30 liter air. Pupuk cair ini disiramkan kelobang tanam cabe, dilakukan tiap minggu.

3)Tips untuk mendapatkan memperoleh harga cabe mahal (Rp 50.000-Rp 100.000) per kg. Caranya dengan rotasi tanam yang terus menerus, setiap 2 bulan sekali ada penanaman cabe baru dilokasi yang berbeda walaupun tidak luas, tapi setiap minggu selalu ada panen cabe tanpa terputus.

Setelah pemberian materi dilajutkan dengan sesi tanya jawab. Pada sesi tanya jawab diharapkan terjadi sharing informasi antara petani cabe, nara sumber dan mahasiswa. Petani bisa bertanya apapun tentang cabe kopay, nara sumber menjawab terkadang juga ada masukan dan tambahan dari mahasiswa yang punya pengalaman berwirausaha tanaman muda, terutama cabe. 
Permasalahan dilapangan yang dialami petani cabe : 1)Para petani cabe di Simpur kesulitan air untuk penyiraman tanaman cabe pada musim kemarau, hanya mengandalkan air hujan. 2)Para petani cabe di Simpur, kebanyakan tidak memberikan pupuk terdahap tanaman cabe, hanya mengandalkan humus dari tanah. 3)Kebanyakan belum memakai mulsa. 4)Jenis cabe yang ditanam bukan cabe kualitas unggul.

Dilanjutkan praktek Lapangan Menanam Cabe Kopay, dengan memakai lahan tidur disetiap dusun di kampung simpur dibuka lahan untuk penanam cabe kopay. Pada awalnya direncanakan penanaman hanya dilakukan pada 1 lokasi, berhubung antar dusun jaraknya lumayan jauh dengan kondisi jalan yang tidak bisa ditempuh kecuali dengan mobil double kabin maka lokasi penanaman dilakukan di tiga tempat yakni disetiap dukun.

Pembukaan lahan dilakukan oleh mahasiswa, masyarakat, aparat kampung dengan koodinator dosen pembimbing lapangan. Setiap lokasi membuka lahan untuk tanaman cabe kopay lebih kurang 200 meter. Praktek lapangan terdiri dari kegiatan-kegiatan: 1)Dimulai dari landclearing, pembersihan tanaman dari rumput liar, 2)Penggemburan dengan cangkul, 3)Membuat bedengan, 4)Pembibitan, 5)Pemberian pupuk dasar, 6)Pemasangan Mulsa, 7)Penanaman, 8)Perawatan.

Setelah masa KKN PPM penanaman dan perawatan cabe kopay di serahkan pada aparat kampung masingmasing dibawah koodinator Pak dusun. Tapi dosen pembimbing lapangan dan mahasiswa tetap datang ke lokasi untuk melihat perkembangan pertumbuhan cabe kopay dan memberi informasi bagaimana melakukan perawatan terhadap cabe kopay.

\subsection{Pengendalian Hama Secara Alami}

Adapun hasil capaian pada program pengendalian hama adalah : 1)Masyarakat mulai paham apa itu hama dan mau ikut berpartisipasi dalam kegiatan pembuatan perangkap hama, 2)Perbaikan teknologi melalui pemanfaatan limbah botol mineral untuk pembuatan perangkap hama di kebun secara sederhana, 3)Masyarakat memiliki pengetahuan baru cara membuat perangkap hama menggunakan Antraktan Methyl eugenol, 4)Masyarakat dengan senang hati berpartisipasi dan memberikan izin lahannya untuk dipasang perangkap hama sebagai kebun percobaan pemasangan perangkap hama, 5)Masyarakat menjadi tahu jenis hama yang terdapat pada perkebunan kopi, 6)Masyarakat perlahan semakin memahami bagaimana menanggulangi hama secara terpadu tanpa menggunakan senyawa kimia berbahaya. Jenis luaran yang akan dicapai selanjutnya dan masih dalam proses berjalan untuk program hama adalah : proses identifikasi jenis hama Lalat buah yang didapat di lapangan.
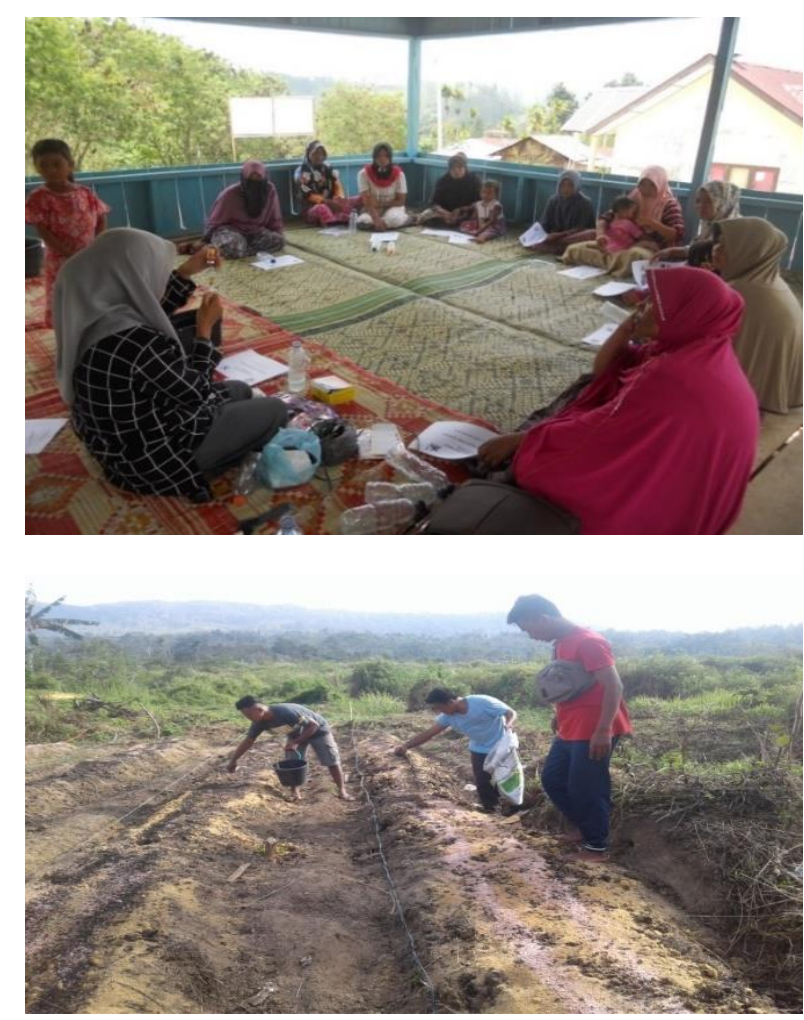

Gambar 5. Penyuluhan dan Pembuatan Perangkap Hama

\section{KESIMPULAN}

Adapun dari kegiatan program KKN PPM berjalan dengan lancar : 1) Setiap warga yang terlibat dalam program ini bersedia berpartisipasi aparat Desa dan Pemda setempat memberi dukungan kepada Tim untuk melaksanakan kegiatan KKN PPM Di Desa Simpur Kec. Mesidah 2)Mahasiswa juga sangat antusias melaksanakan setiap kegiatan, bahkan mahasiswa juga melaksanakan kegiatan mandiri yakni pembuatan gapura setiap dusun, pembuatan tong sampah, dan berbagai perlombaan. 3)Persoalan yang urgen perlu penanganan di desa simpur pada saat ini adalah: perbaikan jalan dan jembatan agar mudah diakses terutama jalan penghubung antar dusun, saluran irigasi, sinyal telepon seluler yang belum ada, deplot pembuatan pupuk kompos. 4)Potensi Desa Simpur yang dapat dikembangkan : perkebunan kopi, tanaman buah, pertanian komuditi tanaman muda(cabe, bawang, tomat dll) bidang peternakan dan perikanan. 5) Ini adalah pengabdian yang pertama bagi kami yang didanai oleh kemenristekdikti, kami menyadari masih banyak kekurangan, masih tahap belajar banyak pengalaman yang kami dapatkan dari sini, menjadi lebih baik lagi dimasa akan datang

\section{UCAPAN TERIMAKASIH}

Ucapan terima kasih disampaikan kepada Direktorat Riset dan Pengabdian kepada Masyarakat, Direktorat Jenderal Penguatan Riset dan Pengembangan Kementerian Riset, Teknologi dan Pendidikan Tinggi yang telah menyediakan Dana Pengabdian Masyarakat tahun 2018 Skema KKN-PPM. Ucapan terima kasih Kepada semua pihak yang ikut membantu terlaksananya kegiatan ini, Bupati Kabupaten Bener 
Meriah serta jajarannya, Camat Kecamatan Mesidah, Reje, Sekdes dan Masyarakat Desa Simpur. Ucapan terimakasih juga disampaikan kepada Rektor, Ketua LPPM, Dosen DPL dan Mahasiswa yang telah berpartisipasi dalam kegiatan ini.

\section{DAFTAR PUSTAKA}

Mala Y. 2013. Pembuatan Pupuk Kompos dari Kotoran Ternak. BPTP Sumatera Barat. Kementrian Pertanian Republik Indonesia.

Munier, F.F. 2010. Pertumbuhan Aspergillus niger Dalam Proses Biofermentasi Pada Beberapa Ukuran Cacahan Kulit Buah Kakao. Pros. Seminar Nasional teknologi peternakan dan veteriner. Bogor 13-14. Agustus 2009. Puslitbang Peternakan, Bogor hlm. 739-744.

Shahabuddin. 2012. Teknik Pengendalian Lalat Buah Bactrocera sp ( Diptera : Tephritidae ) Pada Pertanian Cabai Menggunakan Perangkap Dengan Isyarat Kimia dan Visual. J.Agroland 19 (1): 56-62. ISSN: 0854-641 x. 